Research Paper

\title{
Use of Ground Cover Plants in Rice Paddy Levee Management in Tochigi Prefecture, Japan. -Selection of Suitable Ground Cover for Levee Management-
}

\author{
Yukitsugu Takahashi, Masami Takahashi, Miwa Takahashi, Haruna Kurita, Norikatsu Yamaguchi, \\ Norihito MoRISHIMA and Takashi OGAKI \\ Research Farm, Faculty of Agriculture, Utsunomiya University \\ 栃木県における被覆植物を利用した畦畔管理に関する検討 \\ 一畦畔管理に適した被覆植物の選定一 \\ 高橋行継・高橋まさみ・高橋美羽・栗田春奈・山口則勝 · \\ 森島規仁·大垣 崇 \\ 宇都宮大学農学部附属農場
}

\begin{abstract}
We conducted a trial using ground cover plants as a labor-saving method for managing levees between rice paddies in Tochigi Prefecture, Japan. The four ground cover species tested were phlox (Phlox subulate L.), frogfruit (Lippia nodiflora), centipede grass (Eremochloa ophiuroides), and pennyroyal (Mentha pulegium). Seedlings were prepared, planted on a levee between rice paddies, and continuously monitored for 2 years. After field planting, the growth, change in ground coverage, regrowth after overwintering, and weed suppression of the four ground cover species were compared to identify ground cover plants suitable for levee management. Frogfruit and pennyroyal, which exhibited the fastest growth in the first year after field planting, also reached full coverage in the shortest amount of time and showed superior weed suppression compared with the two other species. In the second year after overwintering, centipede grass, which grew slowly in the first year, exhibited fast growth, rapid coverage, and superior weed suppression similar to frogfruit.
\end{abstract}

Key Words : centipede grass, frogfruit, levee management, pennyroyal, phlox

\section{Introduction}

In the $4,609,000$ ha of farmland in Japan, paddy fields account for 2,506,000 ha (44.4\%), and levees between paddies account for $6 \%$ (Ministry of Agriculture, Forestry and Fisheries 2009). Levees

2020 年 8 月 11 日受付

2021 年 3 月 16 日受理

Corresponding author

高橋行継 Yukitsugu TAKAHASHI

干 321-4415 栃木県真岡市下籠谷 443

443, Shimo-komoriya, Moka-shi, Tochigi-ken, Japan

E-mail : takahashi@cc.utsunomiya-u.ac.jp are also used as pathways for performing paddy work. If levees are not appropriately managed, they become overgrown with weeds, which not only spoil the scenery, but also hinder movement within paddies and provide a habitat for harmful insects. Thus, appropriate levee weed management is essential. Moreover, levee weed management must be carried out several times in the hottest season of the year, from June to August.

However, 1 million of the 1.5 million full-time agricultural workers in Japan are aged 65 or older (Ministry of Agriculture, Forestry, and Fisheries 
2017). Given the advanced age of the farming population and the strenuous nature of weed management, there is an urgent need to find laborsaving methods for removing weeds from paddy levees. One potential weed control method is the use of ground cover plants to suppress weed growth. The habitats of ground cover plants are to creep over and cover the ground quickly. In agriculture, ground cover plants are used for a variety of purposes, not only on levees, but also in places such as orchards, for labor-saving weed control and soil erosion prevention. Studies have sought to identify suitable ground cover plants and to develop ground coverbased management methods (Hoshina and Maeda 1998, Iriyama and Tachibana 2009). A representative study of the popularization of ground cover plants involved using centipede grass for levee weed management in Shiga Prefecture, Japan (Inoue 2004). Trials using pennyroyal for levee management have been conducted in the Nasu region of northern Tochigi Prefecture, Japan, to control stink bugs that cause pecky rice and to improve the local scenery by beautifying the levees.

In this study, we tested four ground cover species over a 2-year period with an intervening winter to identify ground cover species that are suitable for paddy levee management and weed suppression.

\section{Materials and Methods}

\section{1) Preparation of ground cover plants}

The four ground cover plants species were tested including frogfruit (Lippia nodiflora L.), phlox (Phlox subulata L.), centipede grass cultivar 'TifBlair' (Eremochloa ophiuroides Hack), and pennyroyal (Mentha pulegium). The test plants were maintained in a horticultural greenhouse at the Faculty of Agriculture Research Farm (University Farm), Utsunomiya University, Japan until field planting. Frogfruit plants were provided by the Weed Science Center, Utsunomiya University, and seedlings of phlox were purchased. Centipede grass and pennyroyal plants were grown from seed that was sown on March 23, 2009. Centipede grass seeds (5 g) were scattered in $60 \times 30 \times 3 \mathrm{~cm}$ wetland rice seedling trays filled with $3 \mathrm{~L}$ of moist horticultural soil (Redi-Earth, SUN GRO). A thin layer of the same horticultural soil was sprinkled on top to cover the seeds. Pennyroyal seeds were planted in a 200-cell tray (two seeds per cell) filled to the top with moist horticultural soil (Redi-Earth, SUN GRO). After seeding, the trays were covered with a 'Kenbyo sheet' (Sekisui Chemical Co., Ltd.) until germination to keep the soil from drying out. In addition, to reduce the time required for watering, after germination, the seedling trays and cell trays were placed in a basin filled with water to a depth of approximately $1 \mathrm{~cm}$. On April 10, the roots of the phlox seedlings were planted to no.9 pots from the cell tray in which they were purchased. The roots were separated to create bundles of three plants, which were then planted in commercially available 65-cm long rectangular planters filled to the top with culture soil for rice seedlings. The frogfruit plants were maintained in the same seedling trays in which they were received.

Two plants each of pennyroyal and one plant each of phlox were moved to no. 9 pots on May 12, 2009 and cultivated until field planting. The pots were filled with a commercially available horticultural flowering plant soil mix for pennyroyal and grass soil for phlox.

2) Field plot establishment, field planting, and ground cover management

A test field was established on the eastern slope of an agricultural road running through paddy field 1-2d of the University Farm. A herbicide (glyphosate) was sprayed on April 20 and 28 and May 15, 2009, to eliminate existing weeds. Remaining weeds were mechanically removed by scraping using farm machinery, and the bare ground was prepared by raking. Wetland rice fertilizer (JA Hagano A925, 10-18-16) was applied to the ground cover plots on June 2 as base fertilizer at a rate of $5 \mathrm{~g} / \mathrm{m}^{2}$. The four ground cover species were field planted on June 4. To promote rooting and initial growth, the plots were watered daily for approximately 1 month after field planting. Thereafter, the plots were watered on almost all days when there was no rain or when the soil was obviously dry. Weed management of the test 


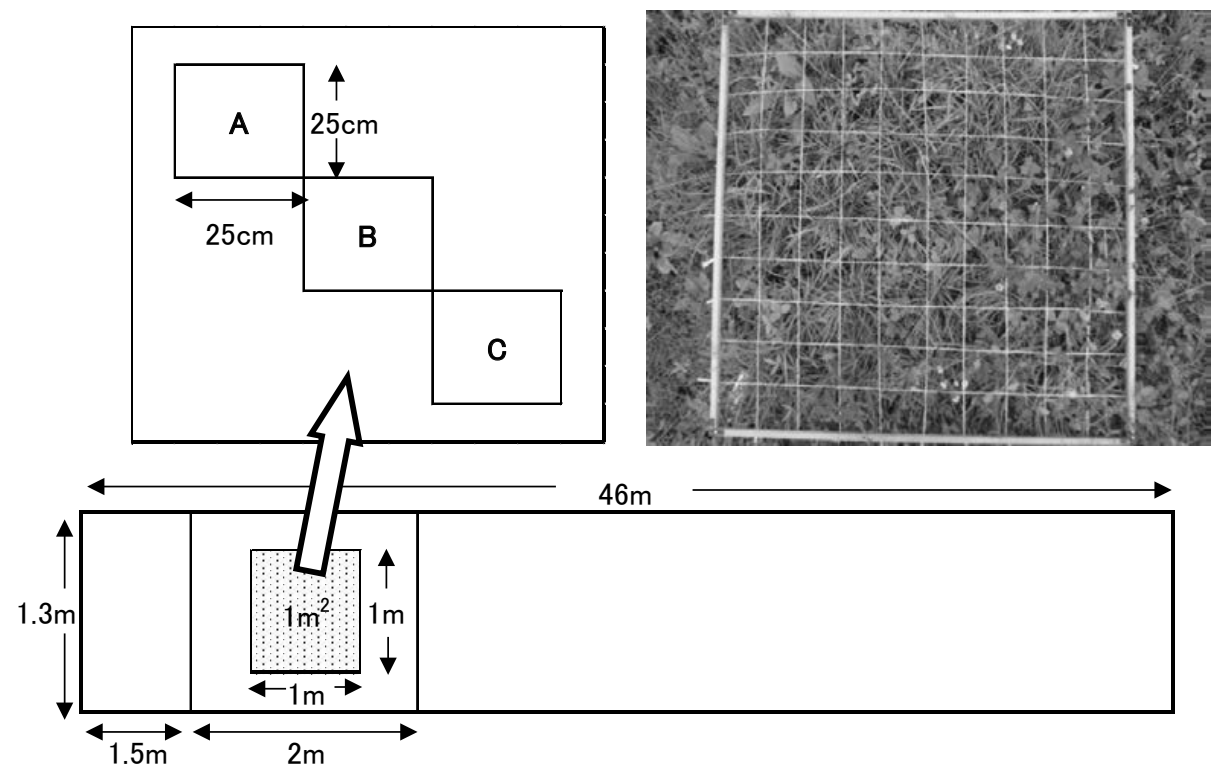

Fig. 1 Diagrams and photo of an experimental plot.

plots was performed once by hand weeding on July 14 and once using a trimmer on August 6.

A scheme of the experimental plots is provided in Fig. 1. The levee of the agricultural road (upper figure) ran $46 \mathrm{~m}$ in a north-south direction, was 1.3 $\mathrm{m}$ wide (in an east-west direction) and had a slope of approximately $25^{\circ}$. A 1 -m border was established on the northern and southern ends of the levee. The remaining area of the levee was divided into 2 -m wide plots. $1 \mathrm{~m}^{2}$ test plots were established in the center of each 2-m wide plot. The four ground cover species were transplanted to these plots (i.e., field planted). Control plots of the same dimensions in which no ground cover plants were planted were also established. Three replicates of each treatment were planted. In 2010, the same test plots were used as in the previous year. Weeds that senesced over winter were removed by hand in April 2010, and weeds were removed by hand on August 6, 2010.

\section{3) Measurements}

The planting density $\left(25\right.$ plants $\left./ \mathrm{m}^{2} ; 20 \times 20 \mathrm{~cm}\right)$ in the levee plots was the same for all four ground cover species. The parameters measured included the number and type of weeds that developed and the percentage of the area covered by ground cover plants. Surveys of the number and type of weeds were conducted in 2009 only. Coverage was also surveyed to monitor the growth and spread of ground cover plants up to complete coverage. Spreading characteristics were used as one criterion for evaluating ground cover species for levee management. $25 \times 25 \mathrm{~cm}$ frame with three replication were placed in a diagonal pattern in the upper left, center, and bottom right of each $1 \mathrm{~m}^{2}$ test plot. The number and types of weeds growing in each frame were monitored and extrapolated for a $1 \mathrm{~m}^{2}$ area. Coverage was calculated by dividing the $1 \mathrm{~m}^{2}$ test plots into 100 uniform cells, with each cell representing $1 \%$ coverage. Weeds and coverage were surveyed a total of eight times at 2 -week intervals after the ground cover plants were field planted on June 4, 2009. Plants that were previously removed from the transport plots for sampling were included in the coverage. After the adjacent paddy field on the west side of the trial area was harvested on November 5 , invaded by the test plants into the paddy field was also surveyed, measured by the distance from the edge of the levee. In 2010, coverage was surveyed a total of 13 times from May 17 to December 16, at 2-week intervals until September 28 and thereafter at monthly intervals. 


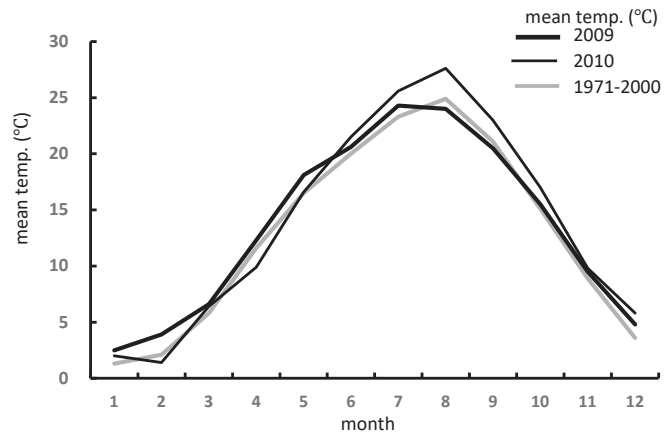

Fig. 2 Change of the monthly mean temperature (2009-10, Moka, Tochigi).

The monthly changes in air temperature and precipitation during the study period from 2009 to 2010 are shown in Figs. 2 and Figs. 3 (Japan Meteorological Agency 2009, 2010). The monthly mean air temperature was above annual (1971-2000) after planting on June 4 and during the root growth period in 2009. However, the monthly average air temperature was below annual in August and September and then above annual from October onward. Monthly precipitation was below annual except during October and December. Monthly precipitation was especially low during June and from July to September during the growth period. It was a warm year in 2010, with the monthly annual air temperature above annual except in February and May.

Monthly mean air temperature was more than $1.5^{\circ} \mathrm{C}$ above annual from June through September during the main growth period of the particular cover plants, and the air temperatures tended to remain high during fall. The monthly precipitation was slightly above annual in 2009 except in August, January, and February. The monthly precipitation during the main growth period from April through September above mean.

\section{Results}

1) Change over time in coverage by different ground cover plants

The change over time in coverage for each of the ground cover species is shown in Fig. 4A. At the time of field planting, the coverage was $10.5 \%$ for all

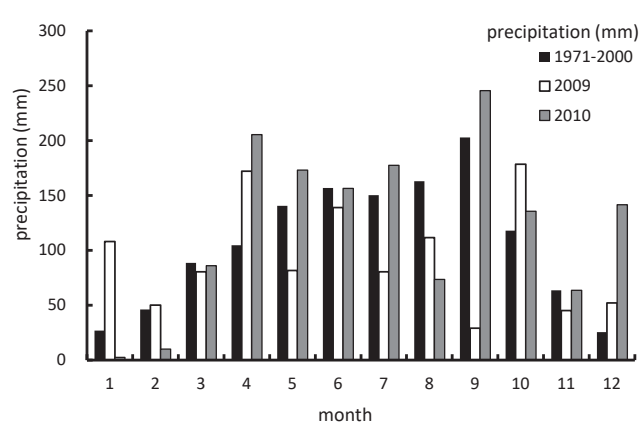

Fig. 3 Change of the monthly precipitation (200910, Moka, Tochigi).

\section{A 2009}
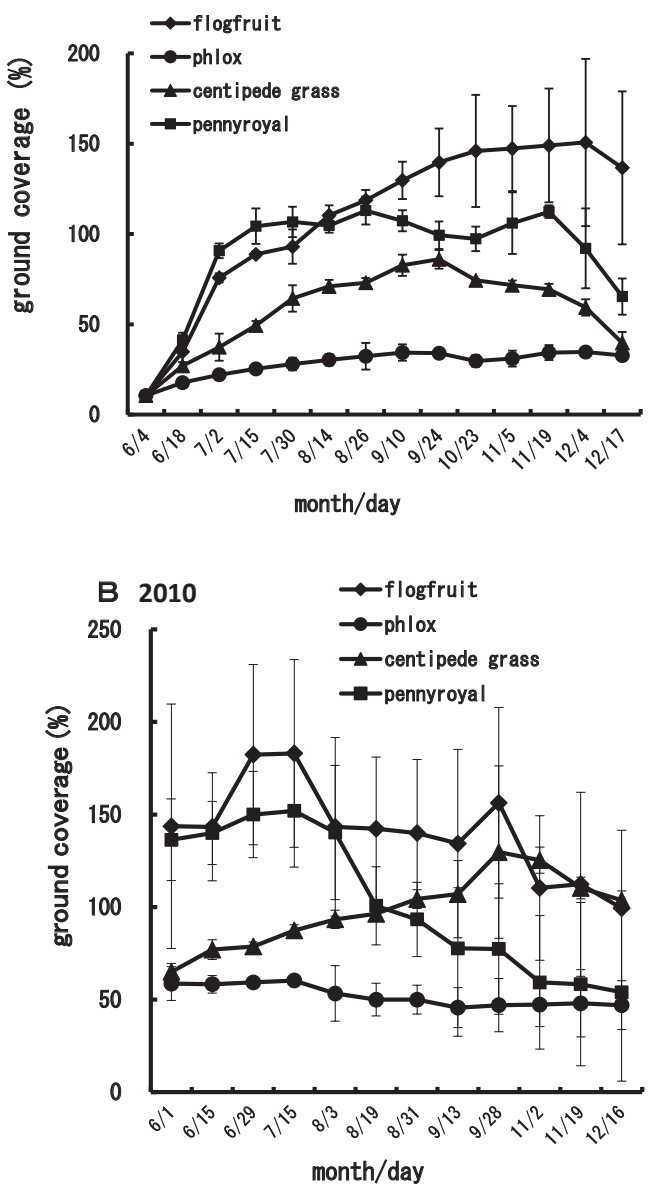

Fig. 4 Change over time in coverage by different ground cover plants $(2009,2010)$. 
Table 1 Chenge over time in coverage by different cover plants $(\% ; 2010)$.

\begin{tabular}{|c|c|c|c|c|c|c|c|c|c|c|c|c|c|c|}
\hline month/day & & $5 / 17$ & $6 / 1$ & $6 / 15$ & $6 / 29$ & $7 / 15$ & $8 / 3$ & $8 / 19$ & $8 / 31$ & $9 / 13$ & $9 / 28$ & $11 / 2$ & $11 / 19$ & $12 / 16$ \\
\hline \multirow{2}{*}{ moss phlox } & inside & 75 & 81 & 85 & 87 & 86 & 81 & 71 & 74 & 68 & 68 & 58 & 58 & 52 \\
\hline & outside & - & 63 & 58 & 95 & 97 & 62 & 71 & 66 & 66 & 88 & 98 & 52 & 58 \\
\hline \multirow{2}{*}{ flogfruit } & inside & 48 & 59 & 58 & 59 & 60 & 53 & 50 & 50 & 46 & 47 & 47 & 48 & 46 \\
\hline & outside & - & 0 & 0 & 0 & 0 & 0 & 0 & 0 & 0 & 0 & 0 & 0 & 0 \\
\hline \multirow{2}{*}{ centipede grass } & inside & 55 & 65 & 77 & 79 & 87 & 93 & 89 & 92 & 94 & 96 & 96 & 95 & 93 \\
\hline & outside & - & 0 & 0 & 0 & 0 & 0 & 7 & 12 & 13 & 34 & 34 & 30 & 32 \\
\hline \multirow{2}{*}{ pennyroyal } & inside & 55 & 53 & 58 & 62 & 62 & 59 & 45 & 41 & 36 & 42 & 27 & 26 & 22 \\
\hline & outside & - & 83 & 82 & 88 & 74 & 81 & 56 & 52 & 42 & 35 & 50 & 33 & 37 \\
\hline
\end{tabular}

The investigation of outside on May 17 was not carried out.

four ground cover species. Frogfruit spread rapidly after field planting, exceeding $100 \%$ coverage and spreading outside the test plots by day 71 . Phlox was the slowest spreading and achieved a maximum coverage of $39 \%$. Centipede grass was the second slowest spreading species and achieved a maximum coverage of $89 \%$. The leaf tips of the centipede grass began to senesce around November, and all above-ground plant parts had died back by the beginning of January 2010. Pennyroyal was the fastest spreading ground cover plant, with some replicate plots exceeding $100 \%$ coverage by day 41 . Senescence due to high temperatures and lack of water was observed starting in early July. Although some subsequent recovery was observed, spreading stopped. This senescence accelerated in the fall. Of the four ground cover species, pennyroyal exhibited the fastest decline in coverage.

Although no difference in coverage was observed between pennyroyal and frogfruit up to June, a difference was observed in July and later. Pennyroyal coverage was greater than that of centipede grass immediately after field planting; however, this difference disappeared in late September. In December, frogfruit coverage was higher than those of the other ground cover species, which were not significantly different from each other.

After the rice harvest, we observed that frogfruit and pennyroyal had invaded into the adjacent paddy field. For frogfruit, penetration was observed in two replicate plots, with a mean invasion distance of 55 $\mathrm{cm}$. For pennyroyal, invasion was observed in all replicate plots, with a mean penetration distance of $11.7 \mathrm{~cm}$ (range: 5 to $15 \mathrm{~cm}$ ).

In 2010, surveys were started on May 17. The change over time in coverage for each of the ground cover species is shown in Fig. 4B. In addition, coverage inside and outside the test plots were different from among 4 species after wintering. Therefore, these results showed in Table 1, except May 17.

On May 17, coverage inside the test plots was highest for frogfruit at $75 \%$. Complete coverage was not achieved in 2010, and the maximum coverage was $87 \%$. On June 1 , coverage by the plants that had spread outside the test plots in the previous year was $63 \%$. These plants spread rapidly, achieving a coverage of $97 \%$ by July 15 , resulting in a combined coverage inside and outside the test plots of $183 \%$. By December 16, the coverage inside and outside the test plots had declined to $52 \%$ and $48 \%$, respectively.

Phlox coverage inside of the test plots was $48 \%$ on May 17. Subsequent growth was slow and resulted in a maximum coverage of $60 \%$. As in the previous year, no spreading outside of the test plots was observed.

As for pennyroyal, regrowth after wintering began in around creeping stems which extended in the previous year, and their growth was good. On the other hand, regrowth after wintering where we planted spot in the previous year, and start time and quantity of regrowth were inferior than around creeping stems which grew in the previous year (Table 1).

Up to August 3, pennyroyal coverage inside the test plots was the same as for frogfruit. On May 17 , coverage was $55 \%$, and a maximum coverage of $62 \%$ was recorded on both June 29 and July 15 . After August 3 , the coverage declined rapidly, falling below that of frogfruit and becoming the lowest of the four 
species. In the last survey on December 16, the coverage was $22 \%$. The coverage outside the test plots on May 17 was $83 \%$, and a maximum coverage of $90 \%$ was recorded on July 15 . Thereafter, coverage declined, falling by $25 \%$ between October 3 and 19 and reaching $32 \%$ by November 2 . The combined coverage inside and outside the test plots reached a maximum of $136 \%$, falling to $65 \%$ in the last survey on December 16.

Centipede grass coverage inside the test plots increased dramatically in 2010. On May 17, coverage was $55 \%$, similar to that of pennyroyal and frogfruit. On July 15 , centipede grass coverage was greater than $80 \%$, higher than that of all other ground cover species, including frogfruit. The maximum coverage inside the test plots, recorded on September 28, was the highest of the four ground cover species. Coverage subsequently remained stable and did not fall below $90 \%$. Spreading outside of the test plots was observed up to August 3, whereas only limited spread was observed thereafter (Table 1). Maximum coverage outside of the test plots was $29 \%$, recorded on November 2. This coverage subsequently declined, falling to $11 \%$ by December 16 . Although the combined coverage inside and outside the test plots was $40 \%$ in the last survey in 2009 , this figure rose to $65 \%$ in the first survey in 2010. This suggests that, although the above-ground parts of centipede grass died back during the winter, the underground parts overwintered and recovered.

Its regrowth start time was after June, and later about 1 month than the other 3 species. However, its residuum stayed to cover the topsoil through previous winter, whereas there were few new invasion of the weeds in the test plots. Although the centipede grass coverage did not increase dramatically like those of pennyroyal and frogfruit, it continued to increase gradually and exceeded pennyroyal coverage on August 19 and frogfruit coverage on November 2. The combined coverage inside and outside the test plots reached a maximum of $125 \%$ on November 2 , before gradually declining to $104 \%$ by December 16 .

Generally, coverage by all four ground cover species was higher in 2010 than in 2009 for the same time of year. However, with the exception of centipede grass, coverage tended to decline after July 15. A particularly steep decline was observed for pennyroyal, with coverage on August 19, 2010 onward being lower than that observed for the same time of year in 2009. Frogfruit coverage on September 28, 2010 onward was lower than that observed at the same time of year in 2009 .

\section{2) Effect of coverage on weed suppression}

Considering that the weed survey was only conducted in 2009, among the weeds observed in test plots were Japanese lawngrass (Zoysia japonica Steud.), Asian flatsedge (Cyperus microiria Steud.), field horsetail (Equisetum arvense L.), marsh dayflower (Murdannia keisak HandMazz.), lawn pennywort (Hydrocotyle sibthorpioides Lam.), cinquefoil (Potentilla atrosanguinea), tufted knotweed (Persicaria longiseta Kitag.), spotted spurge (Euphorbia supina Raf.), California burclover (Medicago polymorpha L.), and Asiatic dayflower (Commelina communis L.). The change over time in number of weeds for each of the ground cover species is presented in Figs. $5 \mathrm{~A}$ to $5 \mathrm{E}$. The figures show the results for Japanese lawngrass and Asian flatsedge, which are the two most prevalent species, broadleaf weeds, and other weeds.

Although some variability was observed in particular test plots, in general, the order of weed prevalence from most to least common was Asian flatsedge, Japanese lawngrass, and broadleaf weeds. The relative distributions of Asian flatsedge, Japanese lawngrass, broadleaf weeds, and other weeds for each of the ground cover species were as follows: $62 \%, 18 \%, 3 \%$, and $23 \%$ for frogfruit; $58 \%, 13 \%, 7 \%$, and $22 \%$ for phlox; $56 \%, 16 \%, 5 \%$, and $23 \%$ for centipede grass; $62 \%, 21 \%, 3 \%$, and $11 \%$ for pennyroyal; and $56 \%, 16 \%, 9 \%$, and $19 \%$ for the control plots. These numbers were total observed weeds number per each plot during an examination period, 2009. The maximum number of weeds was recorded on day 70 (August 13) for frogfruit, centipede grass, and pennyroyal, on day 55 (July 29) for phlox, and on day 40 (July 14) for the control plots. Next to the control plots, the order of 

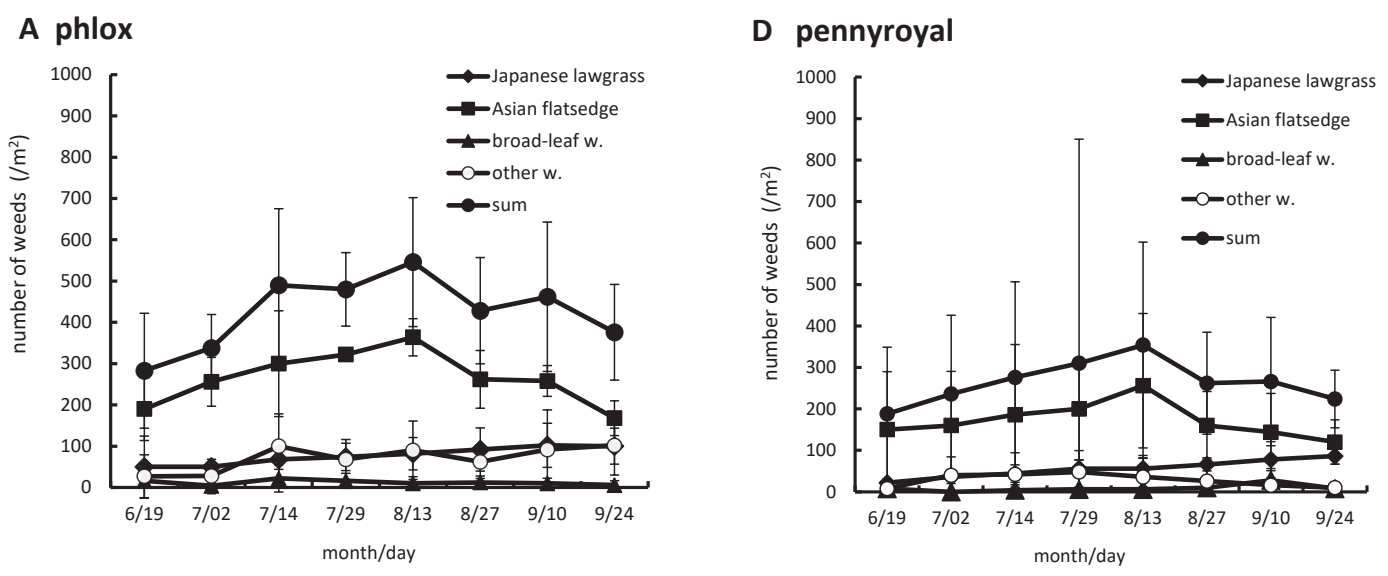

\section{B frogfruit}

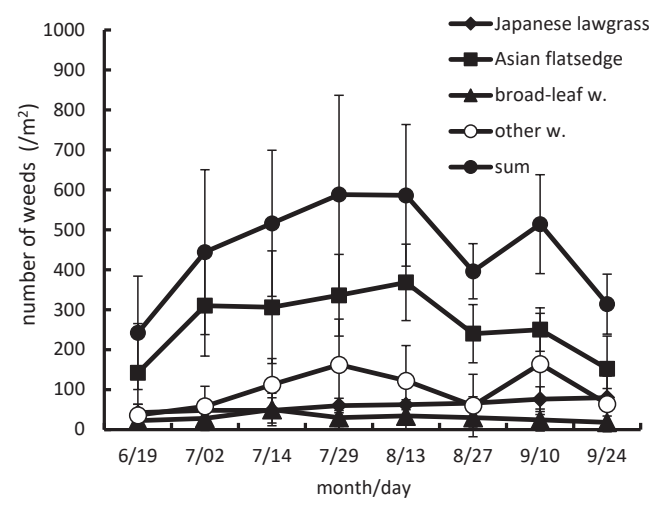

\section{C centipede grass}

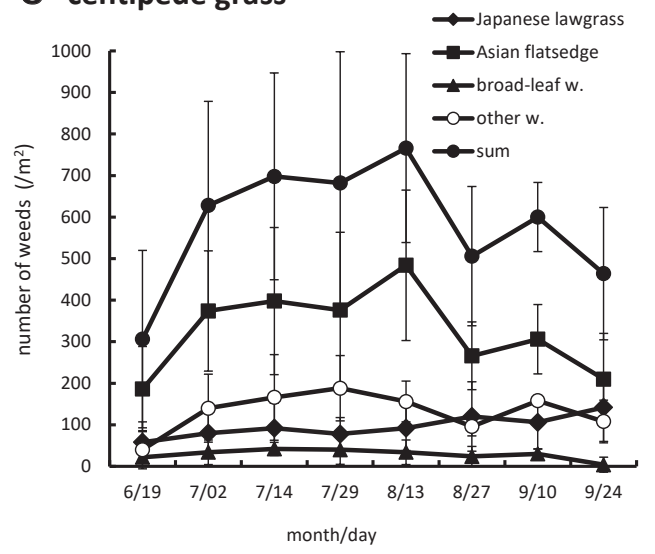

ground cover species from greatest to least number of weeds was centipede grass, phlox, frogfruit, and pennyroyal. No significant difference in the number of weeds was observed between centipede grass and phlox for any of the survey dates; no significant difference was observed between centipede grass,

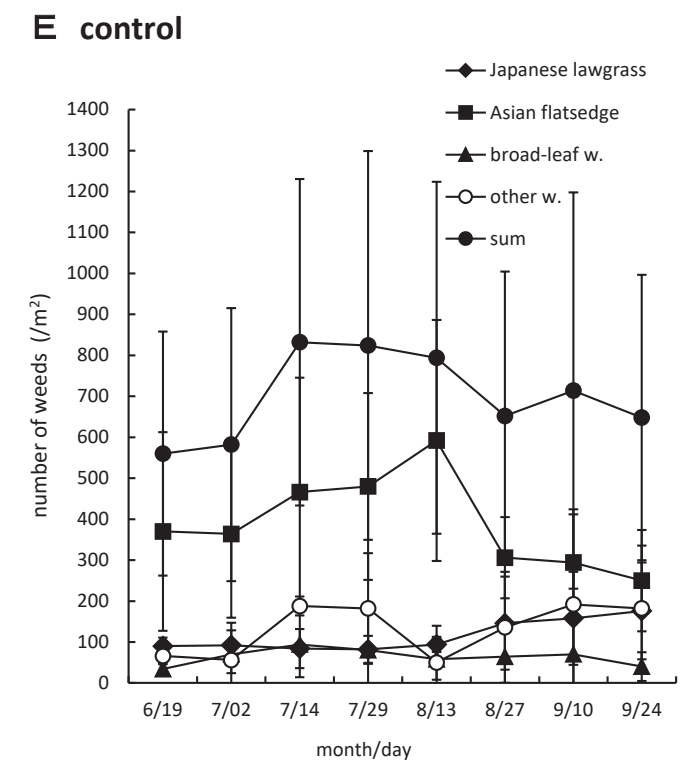

Fig. 5 Effect of coverage on weed suppresion. Error bars represent standard deviation.

phlox, and frogfruit from July 29 onward; and no significant difference was observed between any of the ground cover species from August 27 onward. The number of weeds was significantly lower for pennyroyal than the other ground cover species up to the August 13 survey. 


\section{Discussion}

All the ground cover plants tested over the 2-year period suppressed weeds when planted in the field. In the ground cover plants tested, phlox resulted in a low number of weeds despite its lower ground coverage. Although phlox has been reported to spread rapidly in the spring of the year after planting, leading to increased coverage (Otani et al. 2007), In this field trial, although monthly mean air temperature in April 2010 was below, but it was above after April. Similarly, monthly precipitation was equal or over from April to July than annual monthly precipitation. Therefore, we thought that grow condition was good (Figs. 2 and 3). Whereas, we did not observe such growth in this field trial. However, according to Fujii et al. (1996), Shiraishi et al. (1999), and Kaku et al. (2007), phlox exhibits allelopathic activity, suggesting that it may have suppressed weeds despite its limited ground coverage.

Although centipede grass coverage reached approximately $80 \%$ in September 2009, a large number of weeds also grew. This may have occurred because ground coverage was low when the weeds started to emerge and because centipede grass tends to grow upwards rather than sideways, leaving spaces between individual plants that allow weeds to emerge. However, in the second year, August 2010 , its coverage reached $100 \%$ and there were few weeds due to the formation of dense ground cover. Although centipede grass has the disadvantage of requiring more time to achieve full coverage than the other ground cover species tested, once full coverage is achieved, it may be suitable for paddy levees management.

Pennyroyal spread rapidly and reached sufficient coverage even in the first year of the study, and the number of weeds was significantly lower than for the other ground cover species. This robust weed suppression effect probably arises because the spread of ground cover soon after field planting is faster than weed germination and the dense ground cover prevents sunlight from reaching the soil surface. Furthermore, pennyroyal exhibits weak allelopathic activity (Shiraishi et al. 1999), which may have influenced the number of weeds that grew. On the other hand, in 2009, many plants wilted due to high air temperatures, resulting in a decline in ground coverage. This was perhaps because in 2009, growth after field planting was robust and luxuriant, whereas the amount of precipitation in July and August was approximately half that in an annual year (Japan Meteorological Agency 2009) creating dry conditions. In addition, the west-facing test levee received the westering sun over much of the day (Figs. 2 and 3). Furthermore, in 2010, after overwintering, regrowth was not necessarily sufficient. This, because after overwintering, Pennyroyal, its creeping shoot which grew previous year regrown, mainly. On the other hand, around plantation stock which planted on previous year regrowth was poor (Table 1). And coverage tended to decline from the summer months onward. Furthermore, ground coverage declined after summer, gradually. 2010 was the typical hot summer, the monthly mean air temperature from July through September were much higher than annual mean air temperature. Especially, monthly air temperature on August was $27.6^{\circ} \mathrm{C}$, it was $2.7^{\circ} \mathrm{C}$ higher than $24.9^{\circ} \mathrm{C}$ in annual mean air temperature (Fig. 2). The monthly precipitation in July and September were more than monthly mean precipitation. However, monthly precipitation in August was $73.5 \mathrm{~mm}$, it was $45 \%$ for $163.0 \mathrm{~mm}$ in monthly mean precipitation in August (Fig. 3). Thus, August in 2010 was severe environment for high temperature and dry condition. Therefore, we supposed that weeds produced by the coverage decline, but weather condition in August was reduce to produce weeds.

Thus, pennyroyal growth speed was most rapid than the other 3 species, on the other hand, we found that it had week point for hot weather and dry condition.

Appropriate management for maintaining coverage and appropriate site selection are likely challenges in using plants as ground cover.

Frogfruit formed dense ground cover but did not grow luxuriantly and, instead, tended to spread as a thin layer. Thus, frogfruit may be suitable for 
use on levees that also serve as agricultural paths. Frogfruit was also tolerant of high temperatures and dry conditions in summer 2009, and it did not exhibit obvious discoloration or withering despite abnormally high temperatures in summer 2010. Furthermore, its coverage did not decline dramatically during the cold period in December 2009, indicating that it is highly cold tolerant (Fig. 2). On the other hand, because the plant spreads vigorously, it may spread outside of the test site. In situations where such spreading would be problematic, it would be necessary to develop an effective method to prevent spreading, for example, by cutting or otherwise removing plants.

The results of this 2-year study indicate that the ability of ground cover plants to suppress weeds is influenced by a variety of factors. These factors include growth habit; time required to achieve full coverage; growth-related environmental variables, such as temperature and precipitation; and the plants' allelopathic characteristics. Besides, the influence between weed suppression among 4 ground cover plants were conducted in 2009 only (Figs. 5A to $5 \mathrm{E}$ ). As the experimental field was prepared recently, we suppose that weed spices and their amount will change in the test plots, gradually. The choice of a suitable ground cover plant depends on the local natural environment, type of farm operation, farmer's age, economic strategy, as well as other factors. Further investigation taking these factors into account is needed.

\section{Acknowledgements}

We are grateful to Hitoshi Kuramochi of the Weed Science Center for providing the frogfruit plants used in this study. We would also like to thank the staff of the University Farm for their cooperation and valuable advice related to the field work. Finally, we would like to thank Osamu Kato, Takashi Abe, Kou Urano, Ryosuke Shinozaki, Seiya Nishioka, Ayano Yoshida, Takashi Arai, and Ayaka Nishijima of the Soil Research Lab in the Department of Bioproductive Science (Utsunomiya University) for their cooperation in conducting field work and surveys.

\section{References}

Fujii Y, Kunikata I, Takahashi M (1996): A search allelopathy of cover crop for weed management in paddy ride-a search and small examination by sandwich method, plants box method-, Journal of Weed Science and Technology 33 (Supplement), 76-77.

Hoshina T, Maeda M (1998): Labor saving paddy levee vegetation management by ground cover plants, report 1, the choice for available ground cover species, Journal of Weed Science and Technology (Supplement), 170-171

Inoue T (2004) : A dreamy rice paddy levee cover plants "centipede grass", JAPR Journal 38 (8); 300-305.

Inoue T (2005) : Spreading rice paddy levee “centipede grass", Turfgrass Science 33(2); 127-131.

Inoue T, Kawaguchi Y (2008), Study about centipede grass escape from rice paddy levee, Agriculture and Horticulture 83(7); 765-769.

Iriyama Y, Tachibana T (2009): Character and cultivation of ground cover plants, Journal of Agricultural Science 64 (4); 155-160.

Japan Meteorological Agency; Weather statistics information. Climatological normal (2009 year - month) Moka, Tochigi. http://www.data. jma.go.jp/obd/stats/etrn/view/nml_amd_ym. php?prec_no $=41 \&$ prec_ch $=\% 93 \%$ C $8 \% 96 \%$ D8\%8C\%A7\&block_no $=0338 \& b l o c k \_c h=\% 90$ $\% 5 \mathrm{E} \% 89 \%$ AA\&year $=\&$ month $=\&$ day $=\&$ elm $=$ normal\&view $=(2010 / 1 / 21$ reading $)$.

Japan Meteorological Agency; Weather statistics information. Climatological normal (2010 year - month) Moka, Tochigi. http://www.data. jma.go.jp/obd/stats/etrn/view/nml_amd_ym. php?prec_no $=41 \&$ prec_ch $=\% 93 \%$ C $8 \% 96 \%$ D8\%8C\%A7\&block_no $=0338 \& b l o c k \_c h=\% 90$ $\% 5 \mathrm{E} \% 89 \%$ AA\&year $=\&$ month $=\&$ day $=\&$ elm $=$ normal\&view $=(2020 / 5 / 10$ reading $)$.

Kaku R, Ito S, Ito K (2007): Weed Management Issues and Dynamics During Establishment of Phlox (phlox sublata L.) Ground Cover Using Geotextile Mulch, Journal of Weed Science and 
Technology 52 (2); 57-65.

Matsubara H (1996): Reduction of the rice paddy levee management time and work model, Weeds and their reduce 33; 65-67.

Ministry of Agriculture, Forestry, and Fisheries (2009): The statistical yearbook of MAFF, Cultivated land area http://www.maff.go.jp/ www/info/bunrui/bun01.html (2010/1/21 reading).

Ministry of Agriculture, Forestry, and Fisheries. (2017): The statistical yearbook of MAFF, Cultivated land area, http://www.maff.go.jp/ www/info/bunrui/bun01.html (2018/3/21 reading).

Otani I, Watanabe O, Fushimi A (2007): Effect of Slope Aspects on the Growth of Ground Cover Plants and Their Soil Conservation Abilities, Kinki $\cdot$ Chugoku $\cdot$ Shikoku agricultural research center report 6; 39-53.

Shiraishi S, Watanabe I, Kuno K, Fujii Y (1999): Weed manegemant using allelopathy of ground cover plants: Official approval for allelopathy activity and pot examination, Journal of Weed Science and Technology 38 (Supplement); 174175.
Weon SS (2001): The study about rice paddy levee management in Japan (2) Weed prevention of rice paddy levee and regional characteristic, JAPR Journal 35 (8); 278-287.

\section{要旨}

杤木県において被覆植物による畦畔管理の省力 化を目指した検討を行った。草種としてシバザク ラ, イワダレソウ, センチピードグラス, ペニー ロイヤルミントの 4 種を供試し, 育苗後水田畦畔 に定植して 2 か年継続して検討した. 各草種の定 植後の生長と被度の推移，越冬後の再生状況と抑 草効果などを比較し，畦畔管理に適した草種の検 討を行った。その結果, 初年目は定植後の生長が 速かったイワダレソウ, ペニーロイヤルミントで 被覆の完成が速く, 抑草効果の面でその他の草種 より優れていた。越冬後 2 年目は供試 4 草種中で 初年目の生育が遅かったセンチピードグラスの生 長と被覆が進み, 抑草効果でイワダレソウと共に 高い評価になった。

$$
\text { キーワード }
$$

イワダレソウ，畦畔管理， シバザクラ，センチピ ドグラス, ペニーロイヤルミント 